\title{
PEMBUATAN APLIKASI KEPENDUDUKAN DESA (SIDUKDeS) DI DESA CIGALEUH KECAMATAN BANTARUJEG
}

\author{
Abdul Kholiq, Lia Lailla Nurjamilah, Dadang Sudirno \\ Universitas Majalengka, Indonesia \\ choliqfastac@gmail.com
}

\begin{abstract}
The government agency at the lowest level is the Office of the Village Head, which is an institution that records population data, especially in the process of making Birth Certificates, Death Letters, Population Data Letters, Moving Letters, and Family Cards (KK). To be able to create convenience, accuracy and speed in population data collection along with reports to higher agencies, namely sub-districts, a computerized data collection system is needed. Problems that are often handled at the urban office about population include data collection of new residents, residents who want to move or mutation, birth and death. In Majalengka University Community Service activities that took place in Cigaleuh Village, the objectives were; Village officials and all staff understand the importance of orderly administration in the organization in the village of Cigaleuh; The community understands the importance of online information in the village of Cigaleuh; Assistance with the village apparatus about the Village Population Application System which was still manual is now simpler with the Application (SIDUKDes).
\end{abstract}

Keywords: Application, Information, Population.

\begin{abstract}
Abstrak
Instansi pemerintah pada tingkat yang paling bawah adalah Kantor Kepala Desa dimana merupakan suatu instansi yang melakukan pendataan penduduk terutama dalam proses pembuatan Surat Kelahiran, Surat Kematian , Surat Pendataan Penduduk, Surat Pindah, dan Kartu Keluarga (KK). Untuk dapat menciptakan kemudahan, keakuratan dan kecepatan dalam pendataan penduduk beserta laporannya kepada instansi yang lebih tinggi yaitu kecamatan, maka diperlukan sebuah sistem pendataan yang terkomputerisasi. Masalah-masalah yang sering ditangani dikantor kelurahan tentang kependudukan antara lain pendataan penduduk baru, penduduk yang mau pindah atau mutasi, kelahiran dan kematian. Dalam kegiatan Pengabdian Masyarakat Universitas Majalengka yang berlangsung di Desa Cigaleuh memiliki tujuan diantaranya; Perangkat desa dan seluruh jajarannya memahami akan pentingnya tertib administrasi dalam oirganisasi di desa Cigaleuh; Masyarakat memahami akan pentingnya Informasi Online di desa Cigaleuh; Terbantunya Perangkat desa soal Sistem Aplikasi Kependudukan Desa yang tadinya masih manual sekarang lebih simpel dengan Aplikasi (SIDUKDes).

Kata Kunci: Aplikasi, Informasi, Kependudukan
\end{abstract}

Submitted: 2020-07-17 Revised: 2020-07-25 Accepted: $2020-07-29$

\section{Pendahuluan}

Peraturan pemerintah Nomor 37 Tahun 2007 menyatakan bahwa urusan adminitrasi kependudukan dikabupaten atau kota dilaksanakan oleh instansi pelaksana. Pelaksanaan pencatatan sipil yang meliputi peristiwa kelahiran, kematian, perkawinan, perceraian, pengakuan anak dikecamatan tertentu dilakukan oleh Unit Pelaksanaan Teknis Dinas (UPTD) instansi pelaksana. Dalam Peraturan Presiden Nomor 25 Tahun 2008 
menegaskan bahwa Petugas Registrasi adalah pegawai negeri sipil yang diberi tugas dan tanggung jawab memberikan pelayanan pelaporan penting serta pengolahan dan penyajian data kependudukan di desa atau kelurahan. Masalah-masalah yang sering ditangani dikantor kelurahan tentang kependudukan antara lain pendataan penduduk baru, penduduk yang mau pindah atau mutasi, kelahiran dan kematian. Selain itu pegawai kelurahan juga membutuhkan laporan statistik jumlah penduduk dan jumlah KK. Terkadang ketika ada seorang penduduk yang pindah tetapi data penduduk tersebut masih tercantum sebagai anggota kelurahan tersebut, akibatnya saat dilakukan penghitungan jumlah penduduk hasilnya tidak akurat.

Sistem informasi kependudukan adalah sistem yang dirancang untuk menangani pengolahan data penduduk, penyimpanan, pencarian dan penyajian informasi. Dizaman yang semakin maju, masyarakat tentumya mengharapkan pelayanan yang lebh baik tentang masalah kependudukan.

Instansi pemerintah pada tingkat yang paling bawah adalah Kantor Kepala Desa dimana merupakan suatu instansi yang melakukan pendataan penduduk terutama dalam proses pembuatan Surat Kelahiran, Surat Kematian , Surat Pendataan Penduduk, Surat Pindah, dan Kartu Keluarga (KK). Untuk dapat menciptakan kemudahan, keakuratan dan kecepatan dalam pendataan penduduk beserta laporannya kepada instansi yang lebih tinggi yaitu kecamatan, maka diperlukan sebuah sistem pendataan yang terkomputerisasi.

Kegiatan Pengabdian Masyarakat ini di laksanakan pada tanggal 18 Juni - 18 Juli 2019 di Desa Cigaleuh Kecamatan Lemahsugih Kabupaten Majalengka. Desa Cigaleuh secara Geografis merupaan salah satu dari 19 desa di kecamatan Lemahsugih Kabupaten Majalengka. Secara Topopografis pada ketinggian 500 meter diatas permukaan laut. Posisi Desa Cigaleuh yang terletak pada bagian kecamatan Lemahsugih Kabupaten Majalengka berbatasan langsung dengan, sebelah barat Desa Sinargalih, dan sebelah timur adalah Klapadua dengan sindanghurip Kecamatan Bantarujeg sebelah utara Desa Mekarmulya Kecamatan Lemahsugih serta sebelah selatan Desa Cipendeuy Kecamatan Bantarujeg.

Pengabdian Masyarakat kali ini diharapkan bisa memberikan pembelajaran dan pengalaman bagi Dosen dan Mahasiswa untuk bisa memutuskan dan menyelesaikan setiap masalah yang timbul. Setiap permasalahan yang terjadi di setiap dusun tidaklah sama, mulai dari masalah pendidikan, sosial dan agama sering muncul dalam kehidupan masyarakat. Maka dari itulah mahasiswa yang mengikuti Pengabdian Masyarakatdi harapkan mampu menyelesaikan setiap permasalahan yang timbul, sehingga tercipta kerukunan dan kebersamaan antar warga desa.

Dengan adanya kegiatan Pengabdian Masyarakat Aparat Desa dan masyarakat merasa terbantu, terutama mengenai Masalah Informasi atau yang berhubungan langsung dengan perangkat komputer dan juga bisa terbantu masalah sistem Kependudukan di Desa Cigaleuh Kecamatan Lemahsugih Kabupaten Majalengka yang masih menggunkan metode manual untuk input data Kependudukan.

Dalam kegiatan Pengabdian Masyarakat Universitas Majalengka yang berlangsung di Desa Cigaleuh memiliki tujuan diantaranya :

1. Perangkat desa dan seluruh jajarannya memahami akan pentingnya tertib administrasi dalam oirganisasi di desa Cigaleuh. 
2. Masyarakat memahami akan pentingnya Informasi Online di desa Cigaleuh.

3. Terbantunya Perangkat desa soal Sistem Aplikasi Kependudukan Desa yang tadinya masih manual sekarang lebih simpel dengan Aplikasi (SIDUKDes).

\section{METODE PELAKSANAAN}

1. Analisis dan Perancangan Aplikasi

Desa Cigaleuh secara Geografis merupaan salah satu dari 19 desa di kecamatan Lemahsugih Kabupaten Majalengka. Secara Topopografis pada ketinggian 500 meter diatas permukaan laut. Posisi Desa Cigaleuh yang terletak pada bagian kecamatan Lemahsugih Kabupaten Majalengka berbatasan langsung dengan , sebelah barat Desa Sinargalih, dan sebelah timur adalah Klapadua dengan sindanghurip Kecamatan Bantarujeg sebelah utara Desa Mekarmulya Kecamatan Lemahsugih serta sebelah selatan Desa Cipendeuy Kecamatan Bantarujeg.

2. Analisis Sistem

Analisis sistem adalah penguraian dari suatu sistem informasi yang utuh ke dalam bagian-bagian komponennya dengan maksud untuk mengidentifikasikan dan mengevaluasi permasalahan-permasalahan, kesempatan-kesempatan, hambatan hambatan yang terjadi dan kebutuhan-kebutuhan yang diharapkan sehingga dapat diusulkan perbaikan-perbaikannya.

3. Identifikasi Masalah

Mengidentifikasi masalah merupakan langkah awal yang dilakukan dalam tahapan analisis, masalah dapat didefinisikan sebagai suatu pernyataaan yang diinginkan untuk dipecahkan.

Masalah inilah yang menyebabkan suatu sasaran didalam sistem tidak dapat dicapai, oleh karena itulah pada tahap analisis langkah awal yang harus dilakukan oleh analisis sistem adalah mengidentifikasikan terlebih dahulu masalah-masalah yang terjadi didalam sistem.

Dari hasil penelitian yang dilakukan mengenai sistem informasi kependudukan pada Desa Cigaleuh Kecamatan Lemahsugih penulis menemukan beberapa masalah antara lain

a) Proses dan pencatatan data penduduk dan pembuatan laporan yang lamban

b) Dalam hal komputerisasi di Desa Cigaleuh Kecamatan Lemahsugih hanya digunakan pengetikan suratsurat bersifat resmi, bukan digunakan untuk sistem pengolahan data penduduk.

4. Analisis Kelayakan Sistem

Sistem baru yang akan digunakan harus diuji kelayakannya terlebih dahulu apakah sistem yang baru akan lebih baik dari sistem yang lama atau sebaliknya. Dalam melakukan analisis kelayakan tersebut terdapat empat parameter yang bisa digunakan, yaitu sebagai berikut:

a) Kelayakan Teknologi

Kelayakan teknoligi berhubungan dengan penerapan sistem teknologi yang ada. Dari segi hardware, Kantor Desa Cigalueh sudah memiliki sebuah komputer sehingga hanya dibutuhkan sebuah printer untuk melengkapi kebutuhan hardware sistem yang baru. Dari segi software Kantor Desa Cigalueh belum menggunakan 
aplikasi khusus untuk mengolah data penduduk. Sedangkan dari segi brainware, sudah ada beberapa perangkat desa yang bisa mengoperasikan komputer. Jadi sistem baru dikatakan layak untuk dioperasikan dan tidak ada hambatan dari segi teknologi.

b) Kelayakan Hukum

Penerapan sistem yang baru tidak boleh menimbulkan masalah dikemudian hari hari karena melanggar dari segi hukum yang berlaku terutama masalah legalitas dari software yang digunakan untuk pendukung sistem. Dalam hal ini perangkat lunak yang digunakan harus sesuai dengan perijinan yang berlaku, sehingga tidak menyimpang dari ketentuan hukum yang berlaku dan tidak akan menimbulkan masalah hukum baik pada saat sekarang maupun yang akan datang. Jadi untuk kelayakan hukum, sistem baru layak dipakai karena tidak melanggar aturan hukum.

c) Kelayakan operasional

Aplikasi kependudukan harus bisa menyelesaikan masalah-masalah yang dialami oleh Desa Cigalueh dibidang kependudukan tentunya. Dengan adanya aplikasi ini informasi yang dibutuhkan akan didapatkan dengan cepat dan tepat waktu. Laporan bulanan kependudukan yang biasanya pembuatannya lama dan merupakan pemborosan waktu pegawai tidak akan terjadi lagi. Pencarian data penduduk yang biasanya pegawai kelurahan tidak sanggup, dengan adanya aplikasi ini maka pencarian data penduduk akan semakin mudah.

Analisis operasional berkaitan dengan sumber daya manusia yang mengunkan sistem baru. Sistem ini dirancang agar mudah dioperasikan. Selain itu nantinya juga akan ada pelatihan kepada para perangkat desa tentang bagaimana menggunakan sistem sistem yang baru. Sehingga sistem baru yang akan dietrapkan dapat dikatakan layak untk digunakan.

d) Kelayakan Ekonomi

Aspek paling dominan dari empat aspek kelayakan sistem adalah kelayakan ekonomi. Tidak bisa dipungkiri bahwa motif instansi untuk membangun sebuah sistem adalah demi keuntungan. Dengan demikian aspek untung rugi menjadi pertimbangan utama dalam pengembangan sistem.

\section{Hasil dan Pembahasan}

1. Kegiatan (Program Kerja)

Adapun kegiatan yang telah dilakukan oleh Dosen dan Mahasiswa Pengabdian Masyarakat Universitas Majalengka sesuai program kerja di Desa Cigaleuh Kecamatan Majalengka Kabupaten Majalengka antara lain :

a) Pembuatan Aplikasi Sistem Kependudukan Desa (SidukDes)

b) Simulasi Aplikasi SidukDes

c) Pelatihan Aplikas SidukDes

2. Unsur yang Terlibat 
Adapun unsur yang terlibat dalam pelaksanaan program Pengabdian Masyarakat Universitas Majalengka adalah perangkat desa yang terlibat dalam pembuatan data kependudukan

3. Hasil Kegiatan

Program kegiatan Pengabdian Masyarakat Universitas Majalengka di Desa Cigaleuh khususnya mahasiswa telah dilakukan dengan semaksimal mungkin, dengan mencurahkan tenaga dan fikiran untuk menjadikan desa Cigaleuh lebih baik dan berkualitas, terutama dalam pendataan kependudukan. Adapun hasilnya adalah sebagai berikut :

a) Dengan adanya Kegiatan Pembuatan Aplikasi SidukDes Mampu mempermudah Perangkat desa Untuk Pendataan Penduduk

b) Dengan adanya Pelatihan Aplikasi SidukDes bisa membuat perangkat desa untuk mengoprasikan Aplikasi Siduk Des .

4. Hambatan dan Cara Mengatasinya

Dalam melaksanakan program Pengabdian Masyarakat di Desa Cigaleuh tidak selalu berjalan dengan lancar, banyak hambatan yang dihadapi oleh peserta Pengabdian Masyarakat. Yang mana hambatanya berbeda antara dusun yang satu dengan dusun yang lain. Namun, hambatan-hambatan tersebut dapat teratasi dengan kekompakan kerja kelompok, sehingga masalah yang timbul menjadi lebih mudah untuk diselesaikan.

Adapun hambatan yang timbul diantaranya :

a) Kurangnya Akses Internet Di Desa Cigaleuh.

b) Rendahnya tingkat pendidikan aparat desa.

c) Rendahnya motivasi dari aparat desa untuk mengikuti pelatihan kurang

5. Solusi Permasalahan

Setelah mengetahui Berbagai Hambatan Yang Terjadi Dalam Kegiatan Pengabdian Masyarakat di Desa Cigaleuh berusaha mengatasi masalah tersebut. Adapun cara mengatasinya antara lain :

a) Memberikan Saran Kepada Perangkat Desa Soal Pentingnya Aplikasi Kependudukan untuk Mempermudah Kerja Perangkat Desa

b) Memberikan saran kepada Kepala Desa Pentingnya Media Onlie.

c) Memberikan motivasi dan saran kepada masyarakat akan pentingnya bermasyarakat dan kehidupan sosial.

d) Memberikan sosialisai dan memotivasi masyarakat sekitar untuk lebih mengembang potensi diri dan lingkungan mereka.

\section{Kesimpulan}

Dalam penjelasan di atas dapat diambil kesimpulan bahwa kegiatan Pengabdian Masyarakat Dosen dan Mahaiswa Universitas Majalengka tahun 2019 di Desa Cigaleuh Kecamatan Majalengka walaupun banyak hambatan yang dihadapi, khususnya di bidang teknologi informas pembuatan aplikasi, namun dengan kerjasama kelompok maka hambatan lebih mudah teratasi dengan hasil yang tidak begitu mengecewakan.

Program kegiatan Pengabdian Masyarakat Dosen dan Mahasiswa Universitas Majalengka tahun 2019 tidak semuanya dapat terlaksana, akan tetapi dengan adanya program baru 
yang telah tersusun dengan baik, maka program kegiatan dapat terlaksana dengan baik meskipun tidak sempurna. Program kegiatan Pengabdian Masyarakat Universitas Majalengka tahun 2019 di Desa Cigaleuh yang telah terlaksana dapat memberikan kesan yang positif terhadap pemerintahan desa, dan perangkat desa sangat terbantu untuk melaksanakan tugasnya terutama dalam melakuan pendataan kependudukan.

\section{Daftar Pustaka}

Al Fatta, Hanif. (2007). Analisis dan Perancangan Sistem Informasi Untuk Keunggulan Bersaing Perusahaan dan Organisasi Modern. Yogyakarta: Andi Offset.

Arief M. Rudyanto. (2011). Pemrograman Web Dinamis menggunakan PHP dan MySQL. Yogyakarta: Andi Ofset.

Arbie. (2004). Manajemen Database dengan MySQL. Yogyakarta: Andi Offset. Jogiyanto, HM. 2005. Analisis dan Desain Sistem Informasi: Pendekatan Terstruktur Teori dan Praktek Aplikasi Bisnis. Yogyakarta: Andi Offset.

Kusrini. (2007). Strategi Perancangan dan Pengelolaan Basis Data. Yogyakarta: Andi Offset.

Sunyoto. (2007). Ajax Membangun Web dengan Teknologi Asynchronouse Javascript \& $X M L$. Yogyakarta: Andi Offset. 